\title{
The Constructivist Theory of Reality in Literary Research $^{*}$
}

\author{
Sri Wiryanti Budi Utami
}

\begin{abstract}
As a sign system, literature is not limited to the imaginative world only. Literature, however, is also a system which involves the author, the work, the reader, and the field of knowledge (society).

Although the facts presented tend to be mental facts, it does not mean that facts in literature cannot be seen as data about the existing social reality. Referring to literature as a sign system, which stresses the mimetic and creative aspects, literature as a construction can be seen as the reflection of reality with two dimensions, subjective and objective. Therefore, the assumption that facts in literature are not the reflections of reality cannot be accepted.

Based on the framework of semiotic thinking which emphasizes literature as a sign system, the social dimension could be applied in literary approaches, one of them is the constructivist theory of reality by Berger and Luckman.

Through the constructivist theory of reality, literature can be analyzed as the reflections of subjective and objective realities. In other words, literary approach can be directed from literature as the product and its author.
\end{abstract}

Keywords: constructivist theory, approach, literary research, sign system, imaginative mimesis, designatum, diadic, triadic, semiotic.

\section{Introduction}

Research does not rely on the thickness of the report produced, but on the solution of the problem analyzed. Research, although it has produced a thick report, does not reach its goal if it does not solve the problem.

The methodology used in a research study can be called an approach. A depiction of an event depends on the approach, that is, on our point of view, which dimension is considered, which elements are expressed, etc.

The constructivist theory of reality is one of the social paradigms or sociological approaches. It studies the social aspects of the event analyzed-- for instance, the social identity and its values, the interrelationship with other groups, the conflict due to need, ideology, etc.

\section{Literary facts as reality}

\section{a. What literature is}

Usually, literature is always related to the field of created or imaginative stories. Generally, imaginative means something, which is related to the fantasy world far from reality. But is literature really a work that is far from reality?

\footnotetext{
* Translated from Bahasa Indonesia into English by Sarah Limuil. 
In Bahasa Indonesia literature is "kesusasteraan", which has its origin in the Sanskrit word "sastra". The stem word is 'sas', which means to instruct, teach, or direct. According to its media and function, literature is a verbal communication, which gives knowledge or information about social and cultural symptoms. Therefore it can be said that literature is actually a reflection of a communication act which is full of ideas, knowledge, and experience of an author toward his/her environment.

As a communication act, literature can be seen as a sign system which involves not only the narrator (the author), the code (the work), the reader, but also the sociocultural aspect (the created world).

Literature as a sign system has both subjective and objective meanings. In its subjective meaning, literature is the author's construction. Through his/her process of idealization, an author expresses what he/she experiences and gains from the surrounding world. In its objective meaning, literature refers to a system which includes several expressing norms, such as language, socio-cultural, and literary norms. Also in this objective meaning, literature is seen as a communication system, which reveals the objective world, the socio-cultural world of the society represented. Even in poetry these subjective and objective elements could be traced.

Air mata yang deras mengalir

Bersumber pada kalbu-MU

(Ingat Aku Dalam Doamu. 19)

Tears flowing rapidly

Their source is in your heart

(Remember Me In Your Prayer. 19)

Sungai

Dari hulu hingga ke muara, berapa kali ganti nama?

Air yang mengalir sama juga, hanya saja bertukar warna

(Sajak-sajak Anak Matahari, 38)

River

From the hill to the sea, how many times does it changes its name?

The flowing water is the same, only the color changes

(The Sun's Son Poems, 38)

The objective image of water is clearly described by the word "flowing". In the first poem, the subjective image shows the emotion related to tears. The phrase "flowing rapidly" is used to represent human feelings, with the emphasis on the word "heart". In the second poem, the objective images of water, hill, and sea are the parts of the river image. The author uses the river image to depict the uncertainty of the course of human life.

These objective and subjective images, as stated by Goldman, that the structure meaning in literature represents the author's world view 'vision du monde', not as an individual, but as the representative of the society or the certain social structure (Teeuw, 1988).

\section{b. Facts in literature}

Although facts refer to some things that exist, they are not always visible. Facts in the literary world, in line with the sociological understanding, include material 
and non material facts. Material facts are parts of the real world whereas non material facts are those things considered real, that exist only in human awareness.

As a creation, literature is colored with facts that come from the author's awareness, or in other words, literature is essentially a construction made by the author. Therefore, the facts in the work are more or less subjective. They cannot be considered as the mirror of what really happens in the real world. As the shadow of a square, it extends more than it is.

Facts that exist in human awareness are also colored by certain human values. According to Durkheim, these non material facts actually exist in and between human awareness. As for Weber, human acts without exception, as long as they show individual involvement can be categorized as social facts.

Referring to Durkheim and Weber, the creation of a literary work actually is not free from the author's awareness of his/her world so that what is expressed as facts do really mirror the social reality. In literary works such as Sri Sumarah, Canting, Bawuk, the main characters' expressions are the reflection of the reality in Javanese natural world. From the titles only it can be assumed that these three literary works are about life in the Javanese society.

Facts realized as some things existing in the literary works are called mimetic. They become a reality that can be approached through mimesis; for examples, visualization, or imitation. As firmly stated by Plato about mimesis, the artistic means do not directly refer to ideal values; art can only imitate or imagine things that are visible in reality. Meanwhile Aristotle mentions that through mimesis art becomes the interpretation of reality, the meaning giver of human existence; art is the knowledge's specific and unique means to imagine human life stages which are perhaps too difficult to communicate through other medias.

Facts in literary works can be called the constructed reality. Referring to the mimetic concept, literature as a work of art is the reflection, imitation, or visualization of reality. This can be traced from the language used as the media. Language in literature is not just denotative, or merely pointing to things with certain meanings. Language in literature is meaningful signs, which have the qualities of designatum, that is, the pictures of reality put in nuances of symbols used according to their contexts and some characteristics of what is going on in the outside world. In this case the author's mood also plays a role in using the language in literature.

Therefore, although they are the mirror of the existing reality, facts as stated by the language in a literary work cannot directly be understood or accepted as a reality. Literary media, which are designative, only make the expressed reality become vague, unreal and ambiguous.

From the sociological point of view, non-material facts as the pictures of reality cannot directly be understood or recognized by people although it is around or inside them. Language as a "significant sign" in expressing reality needs interpretation and consideration. Basically language is different from the "natural sign" which is instinctive and resulting in similar reactions for every body. Language as a "significant sign" does not arouse the same reaction from every body.

As a "significant sign", language as a literary medium involves the comprehension aspect which is not only diadic, but also triadic. It is because the language used is not merely performative - informative, but more performative expressive. 
Facts in the literary world tend to be mental facts, although social facts are included. In this case, there is a dialectic relationship between the mimetic and creative factors. There is never an absolute reality in a literary work. However, it does not mean that a literary work as a fiction cannot describe the existing social reality. It is because basically a good literary work re-creates all dimensions of life, the emotional, moral, individual and social, in a world full of objects.

\title{
c. Literature as construction
}

As construction, literature is never meant to be a photograph which contains every detail of the thing photographed. It is more like a painting, from which the object, the technique, the point of view, the style of the painter can be seen. In a literary work, the author's point of view, approach, methodology, and style can also be seen in the way he/she uses visual and auditory images, personification, the narrative style of the characters.

The author's imagination plays a great role in revealing ideas. Although imagination is important, what is presented is always related to the reality in the society represented. In other words, imagination is not a medium to create a lie, which is out of the natural life reality.

Although imagination is subjective, it always ends in objectivity. It is because basically life reality has both subjective and objective dimensions.

\section{d. The problems of objectivity and subjectivity}

Starting from the idea that literature is a construction created by an author, reality in literary work becomes subjective. Each expression has passed the process of thinking in the mind of a subject. What is expressed has been colored or flavored according to the subject's spectacles or appetite.

In every day life, the subject does not live in emptiness or a "vacuum", his/her awareness is influenced by a culture with all of its aspects. Physical, biological, economic, social, political, and religious surroundings have more or less some influences on him/herself.

In every day life people are evaluated based on their typology or categorization. The easiest way to identify people is by stereotypes, that is, using the specific characteristics and a priori tied to all members of that group. An appraisal like this is based on generalization. Subjectivity toward social groups and races is usually based on the stereotype; therefore, it is very subjective. An author's perception about the surrounding world also shows these objectivity and subjectivity:

\author{
Ya, ya, Pariyem saya \\ Maria Magdalena Pariyem lengkapnya \\ "Inem" panggilan sehari-harinya \\ dari Wonogiri Gunung Kidul \\ Sebagai babu nDara kanjeng Cokro Sentono \\ di nDalem Suryomentaraman Ngayogyakarta \\ Saya sudah trima, kok \\ saya lega lila \\ Kalau memang sudah nasib saya \\ sebagai babu, apa ta repotnya? \\ Gusti Allah Mahaadil, kok \\ saya nrima ing pandum (Suryadi, 35)
}


Yes, yes, Pariyem is my name

Maria Magdalena Pariyem is my full name

"Inem" is my nickname

from Wonogiri Gunung Kidul

As the servant of His highness Cokro Sentono

in the house of Suryomentaraman Ngayogyakarta

I can take it

I am truly relieved

If it is my fate

to be a servant, so be it

The Lord God is fair and just

I take it gladly

In that prose-lyric Linus G, Suryadi, catching the reality of the position of a servant who works for a feudal master in nDalem Suryomentaraman Ngayogyakarto, describes both subjective and objective reality.

\section{Reality construction in literature}

As discussed above, literature as a sign system actually involves four aspects, that is, the author, the work (code), the reader, and the socio-cultural society represented. These four aspects in literature have great influence in literary approaches as the research object.

Semiotic approach reflects the acknowledgement that literature is a sign system. This approach rejects the opinion that literature is an autonomous subject that can be understood in the work itself.

Referring to the content of literary works, I can say that literature also studies people's life as society members. Literature can as well be said as the description of human existence in their social life. This can be traced from the way the author creates his/her work that cannot be taken out from the collective symbolism. Society as a unity does not let the author alone, separated from his/her society. The author's tie to the society in turn will affect setting and style of telling the story through the characters. For example, Arswendo Atmowiloto describes the Javanese reality of life through his characters in Canting:

Bu Bei menunggu.

Kalau tiba-tiba Pak Bei meneriakkan keputusan

$\mathrm{Bu}$ Bei menunggu

Sambil mulai memeriksa hasil batikan satu demi satu

$\mathrm{Bu}$ Bei menunggu.

Sambil ikut makan, dan kemudian menyingkirkan dengan cepat semua hidangan beserta piring dan tempat cuci tangan.

(Atmowiloto, 50-51)

Apakah Pak Bei akan berpikir lain setelah melihat bayinya keenam? $\mathrm{Bu}$ Bei hanya bisa menunggu.

Menunggu adalah pasrah. Menunggu adalah menerima nasib, menerima takdir. Menjalani kehidupan. Bukan menyerah, bukan kalah, bukan sikap pandir. Pasrah ialah mengalir, bersiap menerima yang terburuk ketika mengharap yang terbaik.

Atmowiloto, 82) 
Mrs. Bei is waiting.

In case Mr. Bei speaks out his decision

Mrs Bei is waiting

While she is checking the batiks one by one

Mrs. Bei is waiting.

While eating and then putting all the dishes away.

Will Mr. Bei think differently when he sees the sixth baby? Mrs Bei could only wait.

Waiting is surrendering. Waiting is accepting the destiny, the fate. Living her life. Not giving up, not defeated, not becoming foolish. Surrendering means flowing, ready to get the worst while hoping for the best.

From the quotation above, Amowiloto's perception about the meaning of "pasrah" in Javanese life is clearly seen. Through the characterization of Mrs. Bei as a Javanese individual, Atmowiloto tries to picturize the reality of a Javanese woman's attitude. A Javanese woman should be prepared to accept her husband's decision and ready to serve him.

Through literary works we are often led to the treasury of wise advice on a person's attitude and manner in the society or when the person is alone. Therefore, literature is relevant as a tool to understand the ethical codes either as values and norms or the expectations of the society.

In this sense, literature tends to reveal the reality of human life as social creatures. Literature gives information about how to understand social facts as members of the society. Implicitly or explicitly literature describes a deep thinking system which works in the society. Referring to reality in literature above, literature could be said as social data. Although literature relies on the author's imagination, it cannot be taken out from the dialectic relationship between the creative and mimetic process. This relationship also indicates that when the facts end and the imagination starts will never be known.

Based on the concept that literature is a system, approaches through social studies are relevant enough, and they even sharpen literary analysis. The principles of literature as a system are as the following:

1. A system consists of elements or aspects that are unified as a whole.

2. All elements are influential and dependent on one another, and together they support the function of the system.

3. They are interdependent because each element has also the dimensions of other elements.

Basically, the concept of literature as a system does not deny that literature is a sign system. In the semiotic frame, literature is understood as symbolic signs, or in other words, as signs that need interpretation. Interpreting triadic signs means looking at signs not only as the combination between shape and meaning, but also involving the user. In this case it is obvious that literature should be considered as a created work which involves the author, the reader, and the social world, as a reality full of interpretations.

Referring to the author as an individual who has the freedom in his/her imagination to express either the reality or the social criticism in the society, the author in creating his/her work has appeared as a creative actor of the social reality. 
In line with this, the literary approach which uses social paradigm is the constructivist theory of reality.

The constructivist theory of reality is introduced by Berger and Luckman in their book "The Social Construction of Reality". They see the reality for human every day life as the reality that has been interpreted before, which is experienced subjectively as a meaningful and coherent world.

According to this theory, every day life presents a reality that is interpreted and considered meaningful subjectively. Reality is not given objectively or directly without preassumption. The reality faced by human beings in their social life is actually constructed reality. Therefore, in the framework of interpretation, it is still in the scope of social structure which provides a number of roles, each of which is a stereotype for society members. On one side, this constructivist social theory in literature sees the author's idealization as the result of his/her externalization or interaction with the existing structure (social world). On the other side, it is also about the author's experience in internalizing the world and his/her media. Here the author's hopes and existence can be seen. Through the constructivist theory of reality, idealization reflected in a literary work is considered as a symbolic reality, which can be traced back through interactions with the environment or society (social world) as an empiric reality.

\section{References}

Atmowiloto, Arswendo. (1986). Canting sebuah roman keluarga. Jakarta: Gramedia.

Bagus, I Gusti Ngurah. (1987). Punya: Cenderamata untuk Profesor Emeritus A. Teeuw. Denpasar: Pustaka Siddhanta.

Cassirer, Ernst. (1987). Manusia dan kebudayaan: Sebuah esei tentang manusia. (trans. Alois A. Nugroho). Jakarta: Gramedia.

Kartodirdjo, Sartono. (1993). Pendekatan ilmu sosial dalam metodologi sejarah. Jakarta: Gramedia.

Kayam, Umar. (1986). Sri Sumarah. Jakarta: PT. Pustaka Jaya.

Poloma, Margaret M. (1987). Sosiologi kontemporer. Jakarta Rajawali Press.

Ritzer, George. (1992). Sosiologi ilmu pengetahuan berparadigma ganda. Alimandan (penyadur). Jakarta: Rajawali Press.

Sudjiman, Panuti dan Aart Van Zoest. (1992). Serba-serbi semiotika. Jakarta: Gramedia.

Teeuw, A. (1988). Sastra dan ilmu sastra: Pengantar teori sastra. Jakarta: Girimukti Perkasa.

(1983). Estetik, semiotik, dan sejarah sastra, Membaca dan menilai sastra. Jakarta: Gramedia.

Zoeltom, Andy (Ed.). (1994). Budaya sastra. Jakarta: Rajawali Press. 